
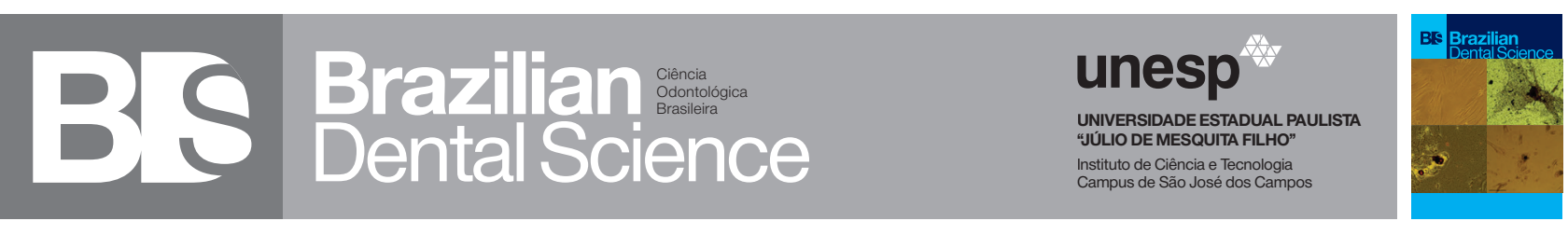

\title{
Evaluation of marginal fit and microleakage of monolithic zirconia crowns cemented by bio-active and glass ionomer cements: In vitro study
}

Avaliação da adaptação marginal e microinfiltração de coroas monolíticas de zircônia cimentadas com cimentos bioativos e ionômero de vidro: estudo in vitro

Radwa Hamdy HASSAN ${ }^{1}$, Ashraf Hassan MOKHTAR ${ }^{2}$, Hanaa ZAGHLOUL ${ }^{1}$

1 - Fixed Prosthodontics Department - Faculty of Oral and Dental Medicine - Misr International University - Cairo - Egypt.

2 - Fixed Prosthodontics - Faculty of Dentistry - Cairo University - Giza - Egypt.

\section{ABSTRACT}

Objective: to evaluate the marginal fit and microleakage of monolithic zirconia crowns cemented by bio-active cements (Ceramir) compared to that cemented with glass ionomer cement, and to evaluate the effect of thermocycling on marginal fit. Material and Methods: Twenty sound human molar teeth were prepared to receive monolithic zirconia crowns. Teeth were divided randomly into two equal groups according to the type of luting cement: Group I (glass ionomer cement) and group II (Ceramir cement). After cementation, the vertical marginal gap was assessed using stereomicroscope before and after thermocycling. Twenty equidistant measurement points were taken for each crown. Leakage assessment was carried out using Fuchsin dye penetration followed by digital photography under a stereomicroscope. Data were analyzed by Mann-Whitney U test to compare between the two luting cements. Wilcoxon signed-rank test was used to evaluate the effect of thermocycling on the marginal fit ( $\mathrm{P} \leq 0.05)$. Results: Whether before or after thermocycling, the results showed no significant difference between the marginal gap values of the two tested groups. For both groups, there was a significant increase in marginal gap values after thermocycling. Also, there was no significant difference between leakage scores of the two tested groups. Conclusion: Similarity in the physical properties and chemical composition of the two cements resulted in a nonsignificant effect on the vertical marginal fit and the extent of microleakage of translucent zirconia crowns. Thermocycling had a negative impact on the vertical marginal gap of the two tested luting agents.

\section{KEYWORDS}

Ceramir; Conventional glass ionomer; Marginal fit; Microleakage; Translucent zirconia.

\section{RESUIMO}

Objetivo: avaliar a adapatação marginal e a microinfiltração de coroas monolíticas de zircônia cimentadas com cimentos bioativos (Ceramir) em comparação com o cimento de ionômero de vidro e avaliar o efeito da termociclagem na adaptação marginal. Material e Métodos: Vinte molares humanos sadios foram preparados para receber coroas monolíticas de zircônia. Os dentes foram divididos aleatoriamente em dois grupos iguais, de acordo com o tipo de cimento: Grupo I (cimento de ionômero de vidro) e grupo II (cimento Ceramir). Após a cimentação, a adaptação marginal vertical foi avaliada com estereomicroscópio antes e após a termociclagem. Vinte pontos de medição equidistantes foram obtidos para cada coroa. A avaliação da infiltração foi realizada utilizando a penetração do corante de fucsina, seguida de fotografia digital sob estereomicroscópio. Os dados foram analisados pelo teste de Mann-Whitney para comparação entre os dois cimentos. O teste de Wilcoxon foi usado para avaliar o efeito da termociclagem na adaptação marginal ( $\mathrm{P} \leq 0,05)$. Resultados: Antes ou depois da termociclagem, os resultados não mostraram diferença significativa entre os valores de fenda marginal dos dois grupos testados. Para ambos os grupos, houve um aumento significativo nos valores de fenda marginal após a termociclagem. Além disso, não houve diferença significativa entre os escores de infiltração dos dois grupos testados. Conclusão: A similaridade nas propriedades físicas e na composição química dos dois cimentos resultou em um efeito não significativo na adaptação marginal vertical e na extensão da microinfiltração de coroas translúcidas de zircônia. A termociclagem teve um impacto negativo na fenda marginal vertical dos dois agentes de cimentação testados.

\section{PALAVRAS-CHAVE}

Ceramir; Ionômero de vidro convencional; Ajuste marginal; Microinfiltração; Zircônia translúcida. 


\section{INTRODUCTION}

$\mathrm{E}$ sthetics and biocompatibility are crucial factors that increased the demand for metal free restorations among patients. Zirconia-based ceramics are a rapidly growing type of esthetic restorations. They are characterized by superior mechanical properties and fracture strength. [1] The use of zirconia ceramics has increased rapidly with the evolution of computer-aided design and computer-aided manufacturing (CAD/ CAM) technology. This technology improved the marginal fit, mechanical durability and predictability of the final restorations [2].

Veneering of zirconia with feldspathic ceramics is mandatory as they suffer from deficient translucent properties. However, this showed a clinical chipping of the veneering ceramic in zirconia restorations. This failure could be due to differences in the coefficient of thermal expansion between the zirconia core and the veneering ceramic, low fracture toughness and flexural strength of veneering ceramic in relation to the zirconia, improper framework design or rapid cooling rates $[3,4]$. In addition, the veneering ceramic failure could be related also to the amount of occlusal load, the size and the location of the occlusal contacts [5], and also to the porcelain thickness [6]. Thus, the introduction of monolithic zirconia "translucent zirconia" offers improvement in the esthetic appearance [7] and the durability of the final restoration compared to veneered zirconia [8].

Clinical longevity of translucent zirconia full-coverage restorations is multi-factorial. The marginal fit and microleakage are among these factors [9]. Vertical marginal gap is the distance between the prepared finish line and the margin of the restoration [9]. Any marginal gap reflects the quality of the marginal adaptation and can influence the amount of leakage which could perhaps be one of the main causes of failure of monolithic zirconia full-coverage restorations [9]. McLean and Von Fraunhofer in 1971 pointed out that the most clinically accepted marginal opening is between 100 and $120 \mu \mathrm{m}$ [10]. Also, marginal gap ranging from 10 to $500 \mu \mathrm{m}$, with mean values from 50 to $100 \mu \mathrm{m}$, has been defined as acceptable. In terms of longevity, marginal openings ranging from 50 to $120 \mu \mathrm{m}$ are considered to be clinically acceptable $[11,12]$. For CAD/CAM restorations, the generally acceptable marginal gap discrepancies are between 50 and $100 \mu \mathrm{m}[13,14]$. Apart from marginal gap, the microleakage is considered one of the main causes of failure that could influence the clinical longevity of indirect restorations [15].

Variations in temperature and $\mathrm{pH}$ in the oral environment are constant changes that affect dental restorations. Morresi et al. assured in their review that thermocycling causes repeated thermal expansion and contractions of the materials used. This leads to the degradation of the dental cement, and fatigue in the interface. Thus it reduces the bond strength which consequently affects the marginal integrity $[16,17]$. Therefore, thermocycling affects the marginal integrity of the restoration leading to microleakage as it is the most commonly-used procedure to simulate the physiological aging experienced by biomaterials in the dental practice [18].

The proper selection of luting agent is considered to be the key factor of long-term success of any fixed dental prosthesis. Different luting agents were analyzed whether by using conventional or adhesive techniques, and only those containing Methacryloyloxydecyl dihydrogen phosphate (MDP) have shown a significant durable bond to zirconia [19-21].

\section{Conventional glass ionomer has} been introduced into the dental field as a hybrid material of silicate cements and polycarboxylate cements to make the best out of the two materials: fluoride release to prevent caries [22] (silicate cement) and adhesion to dental substrates (polycarboxylate cement) [23]. Several studies [7,19,24-26] suggested that, due to its chemical adhesion to 
tooth structure and good biocompatibility as a conventional cement, glass ionomer can be used for cementation of full coverage zirconia restorations.

In the field of dentistry, bioactive materials have been recently introduced to form hydroxy- apatite when immersed in a simulated body fluid (SBF) and saliva [27]. It has been found that bioactive cements could be modified through using calcium aluminate - glass ionomer [28]. Furthermore, it has been concluded that ceramir bioactive cement, a modified type of glass ionomer cement with the addition of calcium aluminate, has remineralizing characteristics and can improve the mechanical properties when used with other additives including, polyacrylic acid, reactive glass, and waterbased content (Doxa, Sweden) [29]. Loof et al. [30] mentioned that the chemistry of ceramir material results in long-term superior sealing properties and biocompatibility in-comparison to glass ionomer cement. Ceramir mimics the natural teeth with low thermal conductivity, and remineralizes the adjacent hard tissue to minimize the risk of thermal shock [31]. Jefferies [32] stated in his comprehensive review part II that the properties of calcium aluminate in Ceramir include better retention and sealing at the interface, biocompatiblity, bioactiveapatite formation, lack of degradation, and stable $\mathrm{PH}$, while the characteristics of glass ionomer include short duration $\mathrm{PH}$, early adhesion to the tooth structure, better flow, and strength properties. Ceramir can be used for permanent cementation of crowns, FDP, inlays, onlays, post and core, high strength zirconia and alumina crowns. Also, after several assessments of cement space, film thickness, setting time, and microleakage using two methodologies; he revealed that Ceramir has less microleakage when compared to conventional glass ionomer [32].

This new bioactive material (bioactive cement) has emerged in the dental field to improve the marginal fit of indirect restorations. However, the capability of this new material to seal the marginal gap by formation of hydroxy-apatite along the tooth restoration interface remains unclear and requires further investigations. Therefore, the aim of the present study was to evaluate the effect of bioactive cement on the marginal fit and microleakage of monolithic zirconia crowns compared to crowns cemented with conventional glass ionomer. The study also aims to evaluate the effect of thermocycling on the marginal fit of monolithic zirconia crowns cemented whether by conventional glass ionomer or by bioactive cements. The first null hypothesis was that there was no significant difference in the marginal fit and microleakage of monolithic zirconia crowns cemented by conventional glass ionomer compared to bioactive cements. The second null hypothesis is that there was no significant difference in the marginal fit before and after thermocycling of monolithic zirconia crowns cemented whether by conventional glass ionomer or bioactive cements.

\section{MATERIAL AND METHODS}

\section{Tooth selection}

Twenty sound human molar teeth were collected from Misr International University (MIU) outpatient clinics after getting the Institutional Review Board (IRB)'s approval (MIU-IRB-1617-044). Teeth were prepared with specific parameters using dental surveyor to receive a full coverage crown monolithic zirconia. The roots of each tooth were embedded in epoxy resin blocks (IN2 INFUSION, easy composites Comp, USA) mixed following the manufacturer's instructions: Epoxy resin powder (polymer) and liquid (monomer) in $2: 1$ ratio. This mixture was poured in a plastic ring (25 mm diameter X $35 \mathrm{~mm}$ height) and before complete polymerization of the mixture, the tooth was mounted into it by the aid of a centralizing device for accurate vertical centralization of the tooth with the long axis of the tooth parallel to the long axis of the plastic ring. 


\section{Tooth preparation}

All teeth were subjected to a standardized preparation using dental surveyor with a straight turbine hand-piece. The base of the surveyor was adjusted to ensure 10 degrees taper with 20 degrees total occlusal convergence as in Figure 1. Under continuous water coolant, the occlusal surface of each tooth was prepared using a wheel-shaped, medium grit abrasive disc (Abrasive disc, 3M ESPE, USA) to flatten the occlusal surface. The axial reduction was performed preserving 4 $\mathrm{mm}$ of axial length with $0.8 \mathrm{~mm}$ wide smooth continuous chamfer finish line by using rounded-end diamond stone. Roundation to all line and point angles and finishing were carried out using the same instrument size with a finer grit.

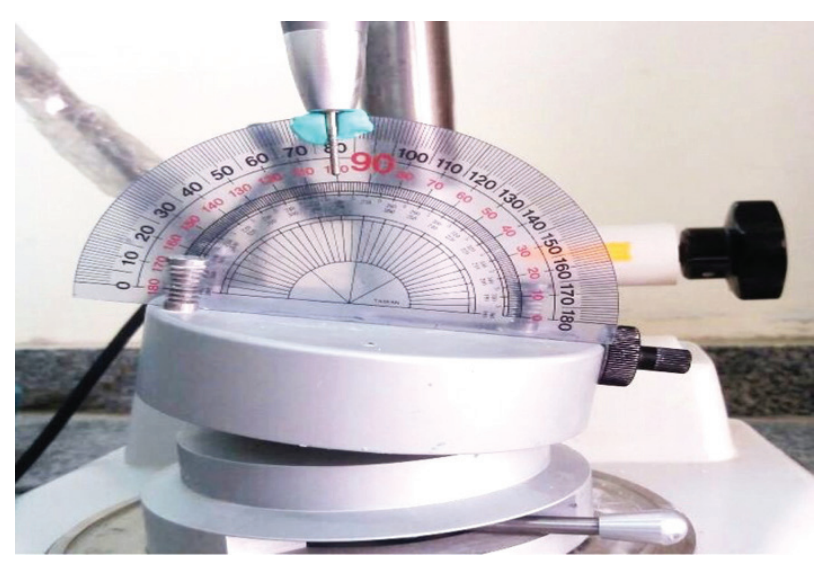

Figure 1 - 10 degrees of taper on each surface.

\section{Zirconia crown construction}

The tooth/ resin assembly was placed on a putty mold that was held to the metal base of the device magnetically and with screws to fix the putty tight on the InEOS X5 scanner (Cerec inEos X5, Sirona Dental Company, Germany). Full contour crowns were designed using CAD software (InLab 3D 16.1, Sirona Dental Company, Germany). The software generates outstanding restoration proposals with minor adjustments when necessary, taking into consideration the insertion axis, margin placement, occlusal, wall thickness, and cement space with 50 microns. The whole design was analyzed from all aspects prior to milling. Before milling, the appropriate disc size (Incoris TZI C 16) was selected in reference to the crown final size by using CAM software (InLab 3D 16.1, Sirona Dental Company, Germany). Milling was performed by means of bur (InLab Sirona milling burs, Germany) (cylinder pointed 20, step bur 20) under continuous coolant. After milling, separation of the crowns from each other and from the disc was carried out by using diamond stone (Diamond stone, Sirona, Germany) held in a straight hand piece. Steamer was used to clean the fitting surface of the crowns from the milling debris and the lubricant remnants. Sintering process was done following the manufacturer's instructions for all the crowns in MihmVogt tabeo furnace (MihmVogt catalogues and technical brochures, Germany) at a sintering temperature of $1540^{\circ} \mathrm{C}$. The duration of the program was approximately 90 minutes following the manufacturer's recommendations.

\section{Randomization}

After sintering and before cementation of each crown to its tooth, Research Randomizer software (https://www.randomizer.org) was used to allocate each sample to its designated testing groups (type of luting cement) randomly.

\section{Cementation}

All the crowns were ultrasonically cleaned with distilled water for $30 \mathrm{~min}$ and dried prior to cementation. For group I, cementation was carried out by using conventional glass ionomer cement (Ketac Cem 3M ESPE, USA) $(n=10)$. For group II, cementation was carried out by using bioactive cement (Ceramir single cap, Doxa, Sweden) $(n=10)$. For each cement, capsules were auto-mixed in an amalgamator following the manufacturer's instructions. Then they were loaded into the fitting surface of the crown and placed over the prepared tooth. Cementation procedure was carried out under a specially designed cementation device 
with 5 kilo grams of static load. Figure 2 each sample was individually placed into the central hole of part a of the cementing device and left under load for 6 minutes to assure complete setting. After setting, the excess cement was removed using an excavator. Group II were immersed in a phosphate buffered saline solution to allow hydroxy-apatite formation for 7 days at $37^{\circ} \mathrm{C}$ in an incubator following the manufacturer's recommendations [32].

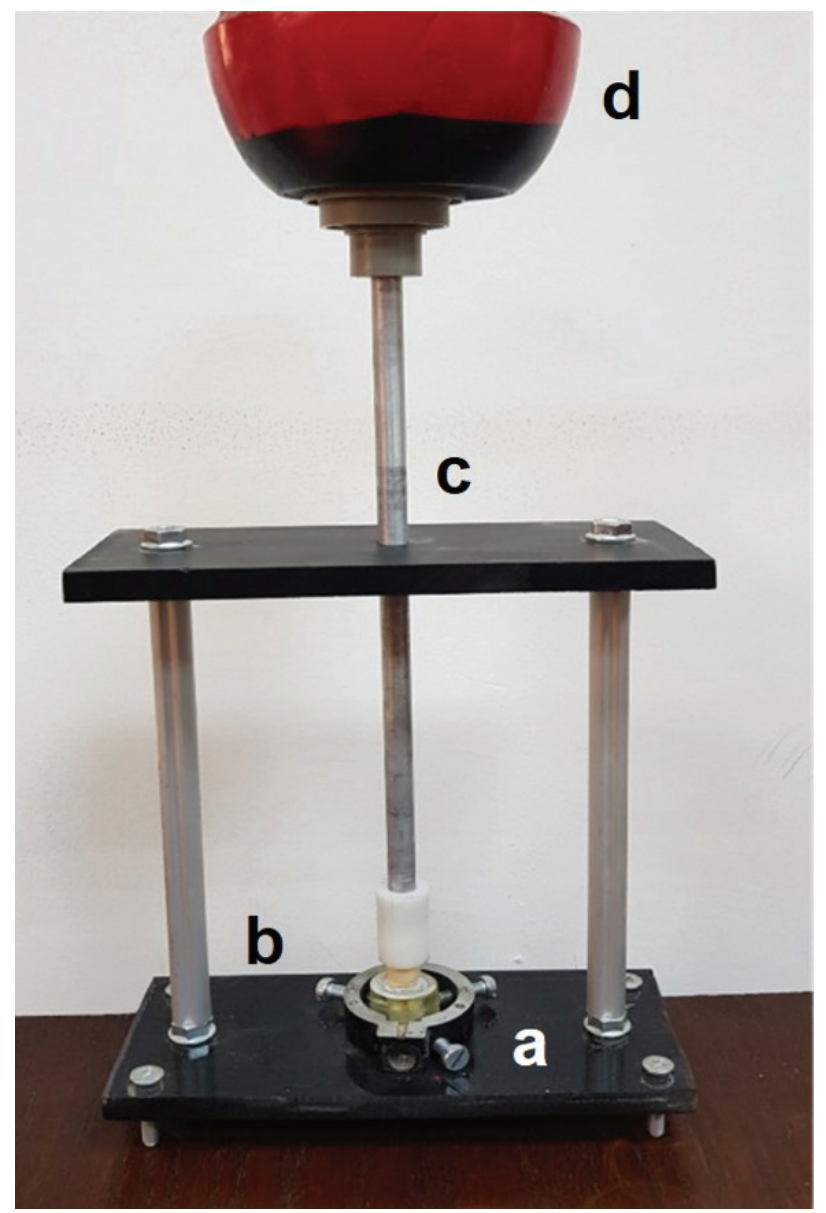

Figure 2 - Cementation device: a; base part; A flat base of aluminium with a central hole to hold the sample in position with screws and attached to two vertical rods carrying a horizontal plate with a central hole where a vertical cylinder pass through.b: a plastic knob; passing through the horizontal plate attached to the vertical cylinder which ends with a plastic knob to allow equal load distribution on the sample. c: vertical cylinder; passing through the horizontal plate hole, it contains a spring to allow its movement vertically that transfers the load from the upper compartment to the lower compartment. d: a load of $5 \mathrm{~kg}$; fits accurately within the cylindrical part having a smooth flat horizontal surface to allow even, equal and stable pressure on the samples without causing eccentric loads.
Thermocycling: All the cemented crowns were subjected to thermocycling (Julabo, Germany) in distilled water for 1000 cycles at changing temperature between $5^{\circ} \mathrm{C}$ and $55^{\circ} \mathrm{C}$ with a dwell time of $20 \mathrm{~s}$ and transfer time of $7 \mathrm{~s}$.

\section{TESTING PROCEDURES}

\section{Marginal fit measurement}

The vertical marginal gap distance for each crown was measured using stereomicroscope (BX60, Olympus, Japan) before and after thermocycling. Images for the margins were taken with a specified camera (DP 10 Camera, Japan) in the microscope with magnification 10X. Figure 3 showed the equidistant measurement points that were taken from each surface ( 6 buccal, 6 lingual, 4 mesial, and 4 distal) with a total of 20 points for each crown. Measurements were recorded in microns and the mean of the twenty points were recorded for statistical analysis. A digital image analysis software (Image $\mathrm{J} 1.43 \mathrm{U}$ image analysis software), was used to measure and evaluate the gap qualitatively. Standardization was made by comparing an object of known size (a ruler) with a scale generated by the Image $\mathrm{J}$ software.

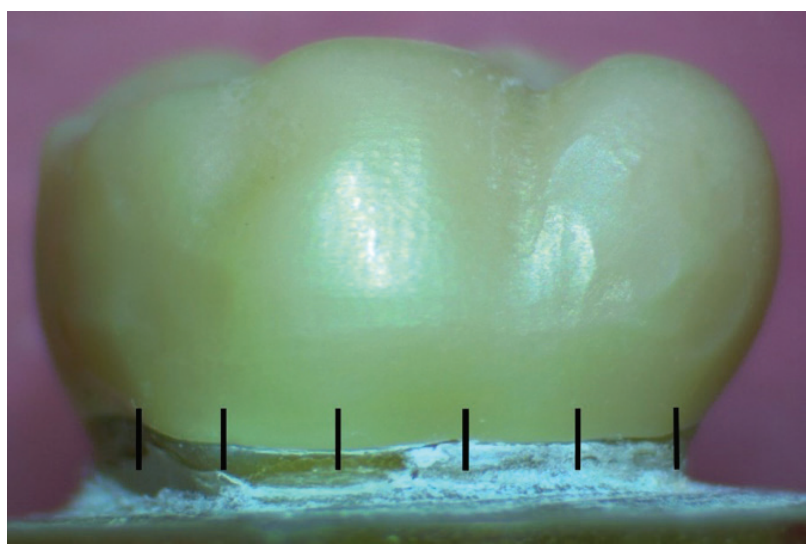

Figure 3 - Equidistant points of measurements on the stereomicroscope. 


\section{Leakage measurement}

In order to assess microleakage, all teeth were covered with nail polish varnish apical to the margin of the restoration by 1 $\mathrm{mm}$ to prevent any dye penetration except at the tooth/crown interface. Then, the teeth were immersed in $0.5 \%$ basic fuchsin dye for 48 hours [33] at $37^{\circ} \mathrm{C}$. By using Isomet saw (Buehler Isomet saw 4000), the crowns were sectioned vertically in a buccolingual direction with low-speed cutting saw of $0.7 \mathrm{~mm}$ thickness abrasive disc, at speed of $2500 \mathrm{rpm}$, under continuous watercoolant. The sectioned tooth was affixed on a stereomicroscope (BX60, Olympus, Japan) to observe the dye penetration of the whole cross section at $10 \mathrm{x}$ magnification.

The dye penetration depths were scored according to $\mathrm{Gu}$ and Kern [34] as follows:

0 : no leakage. 1: $1 / 3$ of the chamfer finish line preparation. $2: 2 / 3$ of the chamfer finish line preparation. 3: all of the chamfer finish line preparation. 4: more than $1 / 3$ of the axial wall. 5 : more than $2 / 3$ of the axial wall. 6: all of the axial walls, including the occlusal edge. 7: exceeding the occlusal edge

\section{Data analysis}

The results were statistically analyzed by Mann-Whitney U test to compare between the two luting cements. Wilcoxon signed-rank test was used to compare between vertical marginal gap distances before and after thermocycling for each cement. The significance level was set at $\mathrm{P} \leq 0.05$.

\section{RESULTS}

In table I, the results showed no statistically significant difference between the vertical marginal gap distance values of the two groups (Ceramir and glass ionomer cements) whether before thermocycling $(P$-value $=0.853$, Effect size $=0.051)$ or after thermocycling $(\mathrm{P}$-value $=0.113$, Effect size $=$ 0.365).
Table I - Median (range) values and results of Mann-Whitney $U$ test for comparison between the vertical marginal gap distance values $(\mu \mathrm{m})$ of the two dental cements

\begin{tabular}{|ccccc|}
\hline Thermocycling & $\begin{array}{c}\text { Ceramir } \\
(\mathbf{n}=10)\end{array}$ & $\begin{array}{c}\mathbf{G I} \\
(\mathbf{n = 1 0})\end{array}$ & P-value & $\begin{array}{c}\text { Effect } \\
\text { size }(\boldsymbol{r})\end{array}$ \\
\hline Before thermocycling & $96.7(55.1-142.1)$ & $100.2(68.1-117.5)$ & 0.853 & 0.051 \\
\hline After thermocycling & $\begin{array}{c}819.4 \\
(541.7-1263.9)\end{array}$ & $\begin{array}{c}986.1 \\
(763.9-1166.7)\end{array}$ & 0.113 & 0.365 \\
\hline
\end{tabular}

*: Significant at $P \leq 0.05$

For both groups (Ceramir and glass ionomer cements), there was statistically significant increase in the vertical marginal gap distance values after thermocycling for (P-value $=0.005$, Effect size $=0.886)$ and for $(P$-value $=$ 0.008 , Effect size $=0.843$ ).

\section{Leakage scores}

As shown in representative samples of microphotographs (figure 4), translucent zirconia luted with glass ionomer cement (group I) presented the following scores of leakage 4; More than $1 / 3$ of the axial wall, 5 ; More than $2 / 3$ of the axial wall, 6; Axial wall including the occlusal edge and 7; Exceeding the occlusal edge. While for group II (Ceramir cement), representative microphotographs (Figure 5) of zirconia samples presented the following scores: 5, 6 and 7. Table (II) summarizes leakage scores of translucent zirconia crowns cemented with glass ionomer and Ceramir cements. Failure of debonding occurred after thermocycling in each group; one sample in group I and two samples in group II.

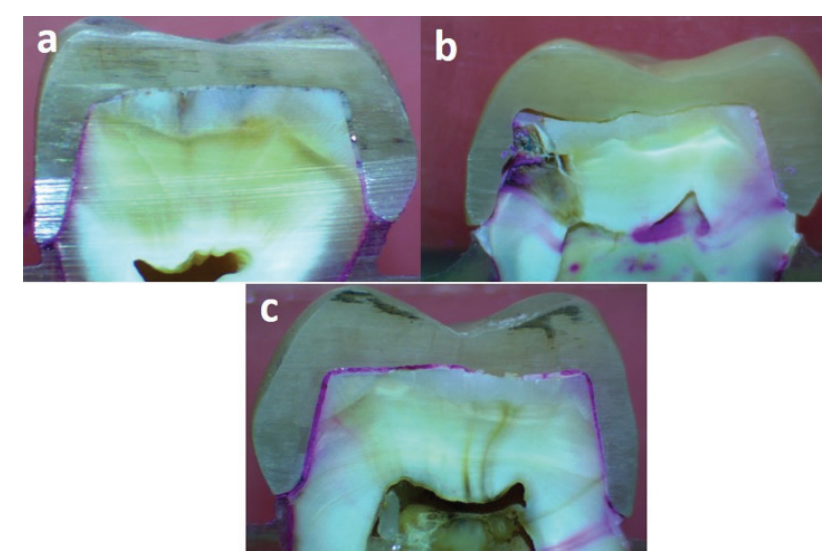

Figure 4 - Stereomicroscope images (group I) exhibit dye penetration: a; to more than $1 / 3$ of the axial wall (4). b; to more than 2/3 of the axial wall (5). c; to all of the axial walls including the occlusal edge (6). d; exceeding the occlusal edge (7) (10 x magnification). 


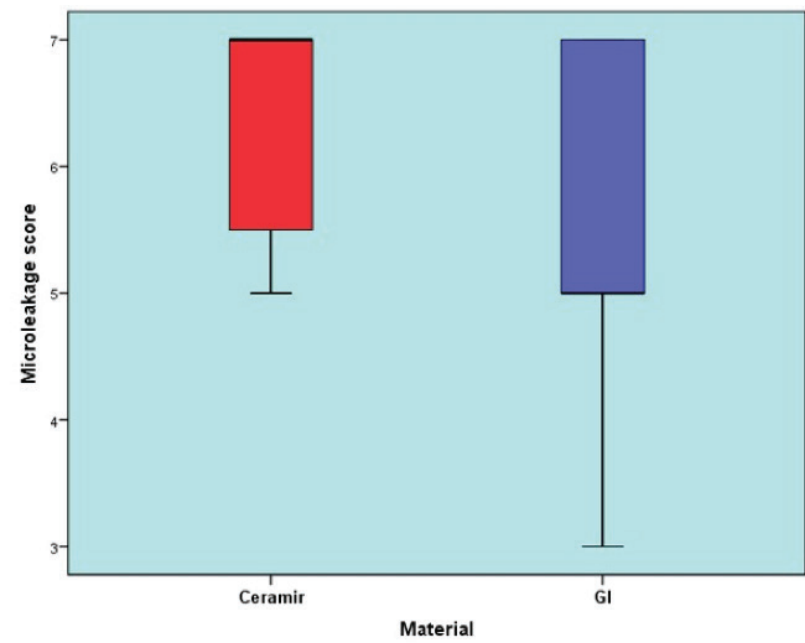

Figure 5 - Stereomicroscope images (group II) exhibit dye penetration: a; to more than $2 / 3$ of the axial wall (5). B; penetration to all the of the axial wall including the occlusal edge (6).c; to exceeding the occlusal edge (7) (10x magnification).

Figure 6 - Box plot representing median and range values for leakage scores of the two- dental cement.

Table II - Leakage scores for translucent zirconia crowns cemented with glass ionomer and Ceramir cement

\begin{tabular}{|ccc|cccc|}
\hline microleak age & \multicolumn{2}{c}{ Glassionomer } & \multicolumn{2}{c}{ Ceramir } & \multicolumn{2}{c|}{ Total } \\
\hline Score & $\mathbf{n}$ & $\%$ & $\mathbf{n}$ & $\%$ & $\mathbf{n}$ & $\%$ \\
\hline 0 & - & - & - & - & - & - \\
\hline 1 & - & - & - & - & - & - \\
\hline 2 & - & - & - & - & - & - \\
\hline 3 & - & - & - & - & - & - \\
\hline 4 & 1 & $11.11 \%$ & - & - & 1 & $11.11 \%$ \\
\hline 5 & 4 & $44.44 \%$ & 2 & $25.00 \%$ & 6 & $69.44 \%$ \\
\hline 6 & 1 & $11.11 \%$ & 1 & $12.50 \%$ & 2 & $23.61 \%$ \\
\hline 7 & 3 & $33.33 \%$ & 5 & $62.50 \%$ & 8 & $95.83 \%$ \\
\hline Total & $\mathbf{9}$ & & $\mathbf{8}$ & & $\mathbf{1 7}$ & \\
\hline
\end{tabular}

Descriptive statistics of leakage scores for Ceramir and glass ionomer groups are presented in table III and when comparing microleakage, no significant difference between the two groups was found (P-value $=0.167$, Effect size $=0.343$ ) (Table (IV), figure 6.
Table III - Descriptive statistics of leakage scores between the two dental cements

\begin{tabular}{|c|c|c|c|c|c|}
\hline \multirow{2}{*}{ Material } & \multirow{2}{*}{ Mean } & \multirow{2}{*}{ SD } & \multirow{2}{*}{ Median } & \multicolumn{2}{|c|}{ Range } \\
\hline & & & & Minimum & Maximum \\
\hline Ceramir & 6.4 & 0.9 & 7 & 5 & 7 \\
\hline Glass ionomer & 5.4 & 1.3 & 5 & 3 & 7 \\
\hline
\end{tabular}

*: Significant at $P \leq 0.05$

Table IV - Median, (range) values and results of Mann-Whitney $U$ test for comparison between leakage scores of the two dental cements

\begin{tabular}{lccc} 
Ceramir $(\mathrm{n}=10)$ & Glass ionomer $(\mathrm{n}=10)$ & $P$-value & Effect size $(r)$ \\
\hline $7(5-7)$ & $5(3-7)$ & 0.167 & 0.343 \\
$*$ *: Significant at $P \leq 0.05$ & &
\end{tabular}

\section{DISCUSSION}

The current in vitro study focused on the differences in the vertical marginal gap and microleakage between the translucent zirconia crowns cemented with glass ionomer and those cemented with Ceramir luting cement, as well as the effect of thermocycling on the marginal fit. The results showed that the vertical marginal fit and leakage scores of translucent zirconia crowns were not affected by the type of the luting cement, and thermocycling significantly increased the vertical marginal gaps of both cements. So, the first null hypothesis was rejected and the second null hypothesis was accepted.

Several methods are available for measuring the vertical marginal gap such as Stereomicroscope, impression replica, crosssectioning, and direct-view technique [35]. Stereomicroscope, which is used in the current study, is considered a non-destructive method for measurement [36]. Moreover, direct imaging technique under a microscope with image analysis software permits a non-destructive quantification and multiple measurements [37]. In the current study, a total of 20 reference points were measured per crown to cover the margin circumferentially. It was supported by a study conducted by Groten et al. [38] They suggested that a range of 20-25 measurements 
per crown was aimed to achieve a precise level close to 50 measurements per crown (optimum number). Thus, it obtained a relevant clinical information about the gap size and assured a statistical accuracy. However, it is difficult to interpret the statistical results of the previous studies because of variation in the sample size, the number of measurements per specimen, and the measurement method used [39-41]. There is no standard method to measure the marginal fit.

Thermal cycling regime is considered the most widely-used procedure to simulate the physiological aging experienced by biomaterials in the dental practice. Consequently, it is routinely employed in experimental studies to evaluate material's performance [25]. In this study, teeth were subjected to 1000 cycles from 5 to $550 \mathrm{c}$ to simulate the oral hot and cold conditions with dwell tie 20 seconds and 7 seconds transfer time [42]. These cycles correspond up to 2 months of clinical function [43].

There are documented methods to identify the microleakage patterns of different restorative materials such as radioactive isotopes [44], air pressure [45], bacteria [46] and neutron activation analysis [47]. However, the still dye penetration method used in the current study remains the most popular and widely used method to evaluate microleakage and is considered the gold standard one. Dye penetration also represents the most reliable quantitative measurement of microleakage. Basic Fuchsin dye and India ink have been used [48]. Penetration of the dye depends on molecular size of the dye, molecular polarity, surface interface and time. Both dye and ink penetration provides a similar sealing ability [33]. In the present study, no significant difference in the vertical marginal gap values were found between the two tested groups before or after thermocycling. These results could be attributed to the similar physical properties and chemical composition between Ceramir and glass ionomer cements. Moreover, it could be attributed to the same internal cement space (50 microns) used during digital designing of the crowns with CAD/CAM technology and the same load during cementation of translucent zirconia with both cements. These results were in accordance with the results of Yuksel and Zaimoglu [24] and Sener et al. [49] They concluded that the standardized internal space and the same load during seating were behind the non-significant difference between the two luting cements (glass ionomer and resin cement).

On the contrary, in a comparative study done by Jefferies et al. [50] to explore whether bioactive dental cement has the ability to seal the marginal gap in comparison to other classes of dental cements. They pointed out that Ceramir can occlude the marginal gap areas. They attributed this to the bioactive properties to form surface-bound apatite mineral in the presence of phosphate buffered saline.

Other studies [24,51,52] revealed that glass ionomer could show an increase in the marginal gap due to the porosities during mixing, thus decreasing the intermolecular contact between the cement and the tooth. Another possible reason is the appearance of micro-cracks as a result of contraction during thermal cycling, which may induce stresses that exceed the cohesive and adhesive strength of the material. Thus, disruption of the cement layer will occur leading to microleakage.

The results of the current study showed that both cement groups (glass ionomer and Ceramir) revealed a significant increase in the marginal gap distance after thermocycling. Surprisingly, this significant increase was not within the clinical acceptable range [52-54]; for group I - conventional glass ionomer (986.1 microns) and for group II - Ceramir (819.4 microns). Several researches [54,55] suggested that thermocycling causes repeated thermal expansion and contractions of the materials used leading to degradation to the dental cement, and fatigue in the interface. Thus, it reduces the bond strength which consequently affects the marginal integrity. A more reliable explanation of this unexpected remarkable increase in the marginal gap values is related to the type of luting agent particularly when using soluble-luting agents such as glass ionomer and Ceramir which dissolute by time due to adverse effect of thermocycling [56]. 
Our results came in accordance with those of Kumar et al's study [57]. They attributed the increase in the marginal gap after thermocycling to the difference in the thermal expansion between tooth, luting agent, and ceramic. Cycling of the restoration between high and low temperature causes rupture of the bond between luting agent and tooth.

The amount of leakage is multifactorial. Among these factors are: restoration construction, luting agents sealing ability, tooth structure, and marginal fit. The leakage scores for both cements in the current study were high, ranging between more than two-thirds of the axial wall to exceeding the occlusal edge (5 scored $69.44 \%$, 6 scored $23.61 \%$, and 7 scored $95.83 \%$ scores) (Table III, Figures 4 \& 5) with no significant difference between them. The significant increase of the vertical marginal gap after thermocycling for both cements as mentioned before was behind the high leakage scores. The results were supported by those of Yuksel et al. [24] and Kumar et al. [57] They concluded that the amount of the marginal gap directly influence the amount of leakage. So, the increase in the marginal gap is one of the reasons for high leakage.

Furthermore, the results of the present study were in accordance with those of Wahab et al. [18] They reported that thermocycling increased the amount of microleakage. Thermocycling affects the marginal integrity of the restoration, causing the microleakage phenomenon that may lead to staining, marginal breakdown, hypersensitivity, and development of pulpal pathology. The non-significant difference in the vertical marginal gap values between the two cement after thermocycling allowed the dye to penetrate into the gaps with the same amount of extent in both cements. This is due to the similarity in the physical properties and chemical composition of the two cements as well as to the standardization in tooth preparation, testing methodology and all the other parameters in the whole study. Also, these results may be attributed to bioactive and remineralization properties of the two tested cements. Previous studies [11,30] compared between glass ionomer and Ceramir cements testing their bioactive behavior. They found that both cements are bioactive, and they can induce a specific biologic response at the tissuematerial interface.

On the contrary, Pameijer et al. [59] and other researchers $[11,45.60]$ conducted studies comparing leakage penetration of Ceramir with other cements, including glass ionomer cement. They found that Ceramir showed the least leakage results. This was due to utilization of the nanotechnology and nano-structure integration that would minimize the leakage over time, as well as to its bioactivity and possible remineralization while forming a natural and durable seal of the tooth-cement interface.

The limitation of the present study is that, as with any in-vitro study, it remains unclear to what extent the marginal fit and microleakage of zirconia crowns cemented with bioactive cement may vary. In the clinical situation, it may vary due to the intraoral environmental variations such as humidity and the continuous function of the teeth in the oral cavity. Besides, this study focused on the extent of leakage rather than on where leakage occurs whether in restoration/ cement interface or cement/tooth interface. Further investigations are required regarding the capability of this new material in terms of remineralization and formation of hydroxyapatite aiming to seal and reseal its marginal interface with tooth structure interface.

The final outcome of our study is that the selection of the luting agent dominates the clinical durability of fixed restorations. Lack of long-term sealing ability of Ceramir and glass ionomer cements affects the marginal accuracy and leakage of translucent zirconia crowns.

\section{CONCLUSION}

Within the limitations of the present study, the following could be concluded:

1. For the two tested cements, the marginal discrepancies achieved by monolithic zirconia 
crowns were within the clinical acceptable range of $120 \mu \mathrm{m}$, while thermocycling had a negative effect on the vertical marginal fit of monolithic zirconia crowns;

2. Similarity of the physical properties and chemical composition of the luting agents resulted in a non-significant effect on the vertical marginal fit and the extent of microleakage of translucent zirconia crowns.

\section{REFERENCES}

1. Helvey GA. Classifying dental ceramics: numerous materials and formulations available for indirect restorations. Compend Contin Educ Dent. 2014 Jan;35(1):38-43.

2. Ting-shu S, Jian S. Intraoral digital impression technique: a review.J Prosthodont 2015 Jun;24(4):313-21. doi:10.1111/jopr.12218. Epub 2014 Sep 14.

3. Cho Y,Raigrodski AJ. The rehabilitation of an edentulous mandible witha CAD/CAM zirconia framework and heat-pressed lithium disilicate ceramic crowns: a clinical report. J Prosthet Dent. 2014 Jun;111(6):443-7. doi: 10.1016/j. prosdent.2013.11.011. Epub 2014 Mar3.

4. Tan JP,Sederstrom D, Polansky JR, McLaren EA, White SN. The use of slow heating and slow cooling regimens to strengthen porcelain fused to zirconia. $J$ Prosthet Dent. 2012 Mar;107(3):163-9. do::10.1016/S0022-3913(12)60050-X.

5. Ishibe M, Raigrodski AJ, Flinn BD, Chung K-H, Spiekerman C, Winter RR. Shear bond strengths of pressed and layered veneering ceramics to high-noble alloy and zirconia cores. JProsthet Dent 2011 Jul;106(1):29-37. doi:10.1016/S00223913(11)60090-5.

6. Sailer I,Philipp A,Zembic A, Pjetursson BE, Hämmerle CHF,Zwahlen M. A systematic review of the performance of ceramic and metal implant abutments supporting fixed implant reconstructions. Clin Oral Implants Res. 2009Sep;20 Suppl 4:4-31. doi: 10.1111/.1600-0501.2009.01787.x.

7. Nakamura K, Mouhat M, Nergård JM, Lægreid SJ, Kanno T,Milleding P,etal. Effect of cements on fracture resistance of monolithic zirconia crowns. Acta Biomater Odontol Scand. 2016 Jan 1;2(1):12-19. Epub 2016 Jan 26.

8. Stober T,Bermejo JL, Rammelsberg P,Schmitter M. Enamel wear caused by monolithic zirconia crowns after 6 months of clinical use. J Oral Rehabil. 2014 Apr;41(4):314-22. doi: 10.1111/joor.12139. Epub 2014 Jan 22

9. Contrepois M, Soenen A, Bartala M, Laviole O. Marginal adaptation of ceramic crowns: a systematic review. J Prosthet Dent. 2013 Dec;110(6):447-454.e10. doi: 10.1016/.jprosdent2013.08.003. Epub20130ct 10.

10. McLean JW, von Fraunhofer JA. The estimation of cement film thickness by an in vivo technique. Br Dent J. 1971 Aug 3;131(3):107-11.

11. Suárez MJ, González de Villaumbrosia P,Pradíes G, Lozano JFL. Comparison of the marginal fit of Procera AllCeram crowns with two finish lines. IntJ Prosthodont. 2003 May-Jun;16(3):229-32.

12. Tan PL, Gratton DG, Diaz-Arnold AM, Holmes DC. An in vitro comparison of vertical marginal gaps of CAD/CAM titanium and conventional cast restorations. J Prosthodont. 2008 Jul;:77(5):378-83. doi: 10.1111/.1532849X.2008.00302.x.

13. Att W, Komine F, Gerds T, Strub JR. Marginal adaptation of three different zirconium dioxide three-unit fixed dental prostheses. JProsthet Dent. 2009 Apr;101(4):239-47.doi:10.1016/S0022-3913(09)60047-0.
14. Akbar JH, Petrie CS, Walker MP,Williams K, Eick JD. Marginal adaptation of Cerec 3CAD/CAM composite crowns using two different finish line preparation designs. JProsthodont. 2006 May-Jun;15(3):155-63.

15. Tay F,Pashley D, Suh B, Carvalho R. Single-step adhesives are permeable membranes. JDent. 2002 Sep-Nov;30(7-8):371-82 .

16. Hakimeh S, Vaidyanathan J, Houpt ML, Vaidyanathan TK, Von Hagen S Microleakage of compomer Class $V$ restorations: effect of load cycling, thermal cycling, and cavity shape differences.J Prosthet Dent. 2000 Feb;83(2):194-203.

17. Morresi AL, D'Amario M, Capogreco M, et al. Thermal cycling for restorative materials: does a standardized protocol exist in laboratory testing? A literature review. J Mech Behav Biomed Mater. 2014 Jan;29:295-308. doi: 10.1016/j. jmbbm.2013.09.013. Epub 2013Sep 27.

18. Wahab FK, Shaini FJ, Morgano SM. The effect of thermocycling on microleakage of several commercially available composite class $V$ restorations in vitro. J Prosthet Dent. 2003 Aug;90(2):168-74.

19. Cristian A-C, Jeanette L, Francisco M-R, Guillermo P.Correlation between microleakage and absolute marginal discrepancy in zirconia crowns cemented with four resin luting cements: An In Vitro Study. Int J Dent. 2016;2016:8084505. Epub 2016 Sep 18.

20. Gargari M, Gloria F,Napoli E,Pujia AM.Zirconia: cementation of prosthetic restorations. Literature review. Oral Implantol (Rome).2010 0ct;3(4):25-9. Epub 2011Jan23.

21. Kern M, Wegner SM. Bonding to zirconia ceramic: adhesion methods and their durability.DentMater. 1998 Jan;14(1):64-71.

22. Habib B, von Fraunhofer JA, Driscoll CF.Comparison of two luting agents used for the retention of cast dowel and cores. J Prosthodont. 2005 Sep;14(3):164-9.

23. Christensen GJ. Why is glass ionomer cement so popular? J Am Dent Assoc. 1994 Sep;:125(9):1257-8

24. Yüksel E,Zaimoğlu A. Influence of marginal fit and cement types on microleakage of all-ceramic crown systems. Braz Oral Res. 2011 MayJun;25(3):261-6.

25. Van den Breemer CRG, Gresnigt MMM, Cune MS. Cementation of glassceramic posterior restorations: a systematic review. Biomed Res Int 2015;2015:148954. doi: 10.1155/2015/148954. Epub2015 0ct 18.

26. Khoroushi M, Keshani F.A review of glass-ionomers: From conventional glassionomer to bioactive glass-ionomer. Dent Res J (Isfahan). 2013 Jul;10(4):411-20.

27. Lööf J, Svahn F, Jarmar T, Engqvist H, Pameijer CH. A comparative study of the bioactivity of three materials for dental applications. Dent Mater.2008 May;24(5):653-9. Epub2007 Aug 28.

28. Jefferies S. Bioactive and Biomimetic Restorative Materials: A Comprehensive review.Part II.J Esthet Restor Dent.2014 Jan-Feb;26(1):27-39. doi:10.1111/ jerd.12066. Epub 2013Dec 17.

29. Jefferies SR, Pameijer CH, Appleby DC, etal. Prospective observation of a new bioactive luting cement:2-year follow-up. J Prosthodont. 2012 Jan;21(1):33-41. doi:10.1111/.1532-849X.2011.00790.x. Epub20110ct31.

30. Loof J,EngqvistH, Ahnfelt N, Lindqvist K, Hermansson L. Mechanical properties of a permanent dental restorative material based on calcium aluminate.J Mater Sci Mater Med. 2003 Dec;14(12):1033-7.

31. Engstrand J,UnossonE, Engqvist H. Hydroxyapatite formation ona novel dental cement in human saliva. ISRN Dent. 2012;2012:624056. doi: 10.5402/2012/624056. Epub 2012 Sep 27.

32 Jefferies SR. Bioactive and biomimetic restorative materials: a comprehensive review.Part..JEsthet Restor Dent. 2014 Jan-Feb;26(1):14-26. doi: 10.1111/ jerd.12069. Epub 2013Dec 17. 
33. Korkut L, Cotert HS, Kurtulmus H. Marginal, internal fit and microleakage of zirconia infrastructures: an in-vitro study. Oper Dent. 2011 Jan-Feb;36(1):72-9. doi: 10.2341/10-107-LR1. Epub 2011Mar 24.

34. GuX-H,Kern M. Marginal discrepancies and leakage of all-ceramic crowns: influence of luting agents and aging conditions. Int J Prosthodont. 2003 MarApr;16(2):109-16

35. Nawafleh A, Florian M, Evans J, Mackay J, Hatamleh M. Accuracy and reliability of methods to measure marginal adaptation of crowns and FDPs: A Literature Review.J Prosthodont. 2013 Jul;22(5):419-28. doi:10.1111/jopr.12006. Epub 2013 Jan 4.

36. Kim HK, Kim SH, Lee JB, Han JS, Yeo IS. Effect of polishing and glazing on the color and spectral distribution of monolithic zirconia. J Adv Prosthodont. 2013 Aug;5(3):296-304. doi: 10.4047/jap.2013.5.3.296. Epub 2013 Aug 31.

37. DuretF,Blouin JL, Duret B. CAD CAM in dentistry.J Am Dent Assoc. 1988 Nov:117(6):715-20.

38. Groten M, Axmann D, Pröbster L, Weber H. Determination of the minimum number of marginal gap measurements required for practical in-vitro testing. $J$ Prosthet Dent. 2000 Jan;83(1):40-9.

39. Iwai T, Komine F, Kobayashi K, Saito A, Matsumura H. Influence of convergence angle and cement space on adaptation of zirconium dioxide ceramic copings. Acta Odontol Scand. 2008 Aug;66(4):214-8. doi:10.1080/00016350802139833.

40. Yucel MT, AykentF,Avunduk MC. In vitro evaluation of the marginal fit of differentall-ceramic crowns. J Dent Sci. 2013;8(3):225-30. doi: 10.1016/j. jds.2012.05.009

41. Yeo IS, Yang JH, Lee JB. In vitro marginal fit of three all-ceramic crown systems. JProsthetDent. 2003 Nov;90(5):459-64.

42. Lameira DP,Silva WAB, Silva FA, De Souza GM. Fracture strength of aged monolithic and bilayer zirconia-based crowns. Biomed Res Int 2015;2015:418641. doi: 10.1155/2015/418641. Epub 2015 0ct21.

43. Lee K-B, Park C-W, Kim K-H, Kwon T-Y.Marginal and internal fit of all-ceramic crowns fabricated with two differentCAD/CAM systems. Dent Mater J. 2008 May;27(3):422-6.

44. Pameijer CH. A review of luting agents. Int J Dent. 2012;2012:752861. doi: 10.1155/2012/752861. Epub2012 Feb 22.

45. Oyagüe RC, Sánchez-Turrión A, López-Lozano JF, Suárez-GarcíaMJ. Vertical discrepancy and microleakage of laser-sintered and vacuum-cast implant-supported structures luted with different cement types.J Jent. 2012 Feb;40(2):123-30. doi: 10.1016/j.jdent.2011.11.007.Epub2011 Nov 15.

46. Piwowarczyk A, Lauer H-C, Sorensen JA. Microleakage of various cementing agents for full cast crowns. Dent Mater. 2005 May;21(5):445-53.
47. Hooshmand T,Mohajerfar M, Keshvad A, Motahhary P.Microleakage and marginal gap of adhesive cements for noble alloy full cast crowns. Oper Dent. 2011May-Jun;36(3):258-65. doi:10.2341/10-253-L. Epub 2011 Jul 8.

48. Toman M, Toksavul S, Artunç C, Türkün M, Schmage P,Nergiz I. Influence of luting agent on the microleakage of all-ceramic crowns. J Adhes Dent. 2007 Feb;9(1):39-47.

49. Sener I, Turker B, Luiz N, Valandro F, Ozcan M, Dent M. Marginal gap, cement thickness, and microleakage of 2 zirconia crown systems luted with glass ionomer and MDP-based cements. Gen Dent. 2014 Mar-Apr;62(2):67-70.

50. Jefferies SR, Fuller AE, Boston DW. Preliminary evidence that bioactive cements occlude artificial marginal gaps. J Esthet Restor Dent. 2015 MayJun;27(3):155-66. doi: 10.1111/jerd.12133. Epub 2015 Jan 30.

51. Mousavinasab SM, Khoroushi M, Keshani F,Hashemi S. Flexural strength and morphological characteristics of resin-modified glass-ionomer containing bioactive glass. JContemp Dent Pract. 2011 Jan 1;12(1):41-6.

52. Adarve RM, James LF.Fixed partial denture self-guided instructional material for dental students; 2011 .

53. Gale M,Darvell B. Thermal cycling procedures for laboratory testing of dental restorations. J Dent 1999 Feb;27(2):89-99.

54. Kokubo Y, Tsumita M, Kano T, Sakurai S, Fukushima S. Clinical marginal and internal gaps of zirconia all-ceramic crowns. J Prosthodont Res. 2011 Jan;55(1):40-3. doi:10.1016/j.jpor.2010.09.001. Epub2010 Oct 8.

55. Martínez-Rus F, Suárez MJ, Rivera B,Pradíes G. Evaluation of the absolute marginal discrepancy of zirconia-based ceramic copings.J Prosthet Dent 2011 Feb;105(2):108-14. doi:101016/S0022-3913(11)60009-7.

56. Heikkinen TT,Matinlinna JP,Vallittu PK, Lassila LVJ.Long term water storage deteriorates bonding of composite resin to alumina and zirconia short communication. Open Dent J.2013 Sep 30;7:123-5. doi: 10.2174/1874210601307010123. eCollection 2013.

57. Kumar T,Bindu H, Shankar Y, et al. Evaluation of marginal adaptation and microleakage of all ceramic crown systems by using two commercially available luting agents-in vitro study. Int J Current Res. 2018;10(8):72760-5.

58. Loof J,EngqvistH, AhnfeltN-0, LindqvistK, Hermansson L. Mechanical properties of a permanent dental restorative material based on calcium aluminate.J Mater Sci Mater Med. 2003 Dec;14(12):1033-7.

59. Pameijer $\mathrm{CH}, \mathrm{Zmener} 0$, Alvarez Serrano S, Garcia-Godoy F.Sealing properties of a calcium aluminate luting agent. Am JDent. 2010 Apr;23(2):121-4.

60. Tinschert J,ZwezD, MarxR, Anusavice KJ. Structural reliability of alumina, feldspar, leucite-, mica-and zirconia-based ceramics. J Dent. 2000 Sep;28(7):529-35.

\section{Radwa Hamdy Hassan} (Corresponding address)

Teaching assistant, Fixed Prosthodontics, Faculty of Oral and Dental Medicine, Misr International University, Cairo-Ismailia road, Postal Code 11828, Cairo, Egypt. Date submitted: 2019 Jul 11 E-mail: radwa062006@miuegypt.edu.eg 